\title{
Effect of substrate temperature on structural and optical properties of spray deposited $\mathrm{ZnO}$ thin films
}

\author{
Y. LARBAH*, M. AdnANe, T. SAHRAoui \\ Laboratory of Electron Microscopy and Materials Sciences University of Science and Technology of Oran, B.P. 1505, \\ 31000 El-Mnaouer Oran, Algeria
}

\begin{abstract}
Undoped $\mathrm{ZnO}$ thin films have been prepared on glass substrates at different substrate temperatures by spray pyrolysis method. The effect of temperature on the structural, morphological and optical properties of n-type ZnO films was studied. The X-ray diffraction (XRD) results confirmed that the $\mathrm{ZnO}$ thin films were polycrystalline with wurtzite structure. Scanning electron microscopy (SEM) measurements showed that the surface morphology of the films changed with temperature. The studies demonstrated that the $\mathrm{ZnO}$ film had a transmission of about $85 \%$ and energy gap of $3.28 \mathrm{eV}$ at $450{ }^{\circ} \mathrm{C}$. The RBS measurements revealed that $\mathrm{ZnO}$ layers with a thickness up to $200 \mathrm{~nm}$ had a good stoichiometry.
\end{abstract}

Keywords: ZnO; spray deposition; Rutherford Backscattering Spectrometry (RBS); structural, optical and electrical properties

(C) Wroclaw University of Technology.

\section{Introduction}

Zinc oxide $(\mathrm{ZnO})$ is a wide band gap $(3.4 \mathrm{eV})$ semiconductor. It exhibits good piezoelectric, photoelectric and optical properties. Hence, it is an ideal candidate to realize optical devices, such as light emitting diodes, transparent conductive films, solar cells [1, 2], sensors [3] and surface acoustic wave devices. $\mathrm{ZnO}$ thin films and nanostructures have been produced by a wide range of growth techniques, including chemical vapor deposition (CVD) [4], magnetron sputtering [5], laser molecular beam epitaxy [6], sol-gel [7] and spray pyrolysis [8-11] Among these methods, spray pyrolysis is appropriate for large area thin film formation and easy doping.

In this work, we present the experimental results of physical properties obtained by various characterization techniques. The thin films under study were deposited by spray pyrolysis technique onto a glass substrate. Due to the fact that this is a chemical technique, the most important parameters are the temperature and deposition time. The substrate temperature has a strong effect on the

*E-mail: djozef84@yahoo.fr deposited $\mathrm{ZnO}$ thin films. A series of thin films has been deposited at different substrate temperatures with keeping the deposition time constant.

\section{Experimental}

Undoped $\mathrm{ZnO}$ thin films have been deposited onto glass substrates at different substrate temperatures. The details of the spray pyrolysis setup are shown in Fig. 1. This method consists in spraying an alcoholic, finely atomized solution by a carrier gas (nitrogen) on a heated substrate; the precursors finally form the thin film. $0.2 \mathrm{M}$ solution of zinc acetate dihydrate $\left(\mathrm{Zn}\left(\mathrm{CH}_{3} \mathrm{COO}\right)_{2} \cdot 2 \mathrm{H}_{2} \mathrm{O}\right)$ diluted in methanol was used for all the films. The starting solution was mixed thoroughly and then it was sprayed. The nozzle-substrate separation used was of $25 \mathrm{~cm}$. During the spraying process, the substrates were heated on an electrically heated plate. The flow of the solution was $2 \mathrm{~mL} / \mathrm{min}$ and gaseous nitrogen was used as a carrier gas. Substrate temperature was controlled by means of thermocouple. After depositing the film, it was allowed to cool to room temperature. In this paper, we discussed the influence of temperature on the structural, optical and electrical properties of 
the deposited films. The investigation of structural properties of the $\mathrm{ZnO}$ thin films was performed through X-ray diffraction (XRD), using the $\mathrm{CuK} \alpha$ radiation $(\lambda=1.54056 \AA)$. The surface morphologies were observed by scanning electron microscopy (ESEM, Philips, XL30-FEG). The sheet resistance was measured by the four-point probe technique and the measurement of transmittance in the range of 300 to $1100 \mathrm{~nm}$, taking air as the reference, was carried out by a UV-Vis spectrophotometer. The thickness and compositional depth profile was studied by Rutherford Backscattering Spectrometry (RBS) using a $2 \mathrm{MeV} 4 \mathrm{He}^{+}$ion beam. The backscattered ions were recorded by a surface barrier detector, placed at $165^{\circ}$ with respect to the beam. The recorded RBS spectra were processed by the RUMP simulation computer program.

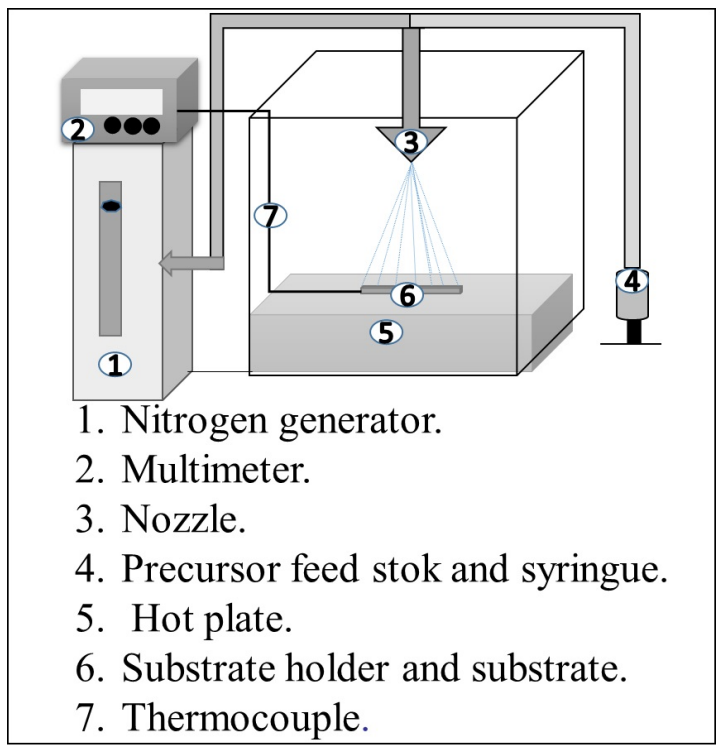

Fig. 1. Schematic diagram of the spray pyrolysis deposition system.

\section{Results and discussion}

\subsection{X-ray diffraction measurements}

Fig. 2 shows XRD spectra of undoped zinc oxide deposited at different substrate temperatures. The films have grown in a hexagonal wurtzite-type structure, confirmed by the data from JCPDS Card No. 05-0664. The films produced at temperatures $400{ }^{\circ} \mathrm{C}$ have an orientation with three dominant peaks: (100), (002) and (101). When the substrate temperature was increased, the (002) diffraction peak became progressively stronger. The same was observed by other authors [12-15]. All the films had one (002) peak which corresponded to $\mathrm{c}$ axis perpendicular to the substrate. Thus, the textured films can be obtained at low and high temperatures but high temperatures lead to larger grain size $[16,17]$. From these results, we can conclude that the thin films showed the preferred orientation along (002) plane. This orientation is the most common for $\mathrm{ZnO}$ layers.

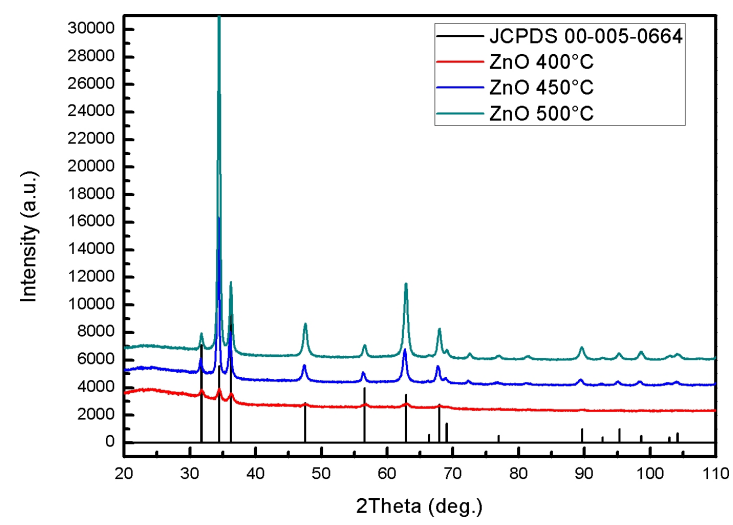

Fig. 2. X-ray diffraction patterns from the $\mathrm{ZnO}$ films deposited at 400,450 and $500{ }^{\circ} \mathrm{C}$.

The average particle size of $\mathrm{ZnO}$ was estimated from X-ray line broadening using the DebyeScherrer equation [18]:

$$
D=\frac{(0.9 \lambda)}{\beta \cos \theta_{(h k l)}}
$$

where $\mathrm{D}$ is the grain size of crystallite, $\lambda=$ $1.54059 \AA$ is the wavelength of $X$-rays used, $\beta$ is the broadening of diffraction line measured at half of its maximum intensity in radians and $\theta$ is the angle of diffraction.

The average grain sizes in different orientations were determined from the diffraction peak width. The results are shown in Table 1 . When the substrate temperature is increasing, the grain sizes is increasing in the direction (002). 
The lattice strain $\varepsilon(\%)$ was estimated from $\mathrm{X}$-ray line broadening using equation 2 [18]:

$$
\varepsilon \%=\frac{\beta}{4 \tan \theta}
$$

The lattice constants a and c were determined from the XRD patterns using the formula 3 [19]:

$$
\frac{1}{d_{h k l}}=\sqrt{4 / 3\left(\frac{h^{2}+k^{2}+h k}{a^{2}}\right)+\frac{l^{2}}{c^{2}}}
$$

The calculated lattice parameters are reported in Table 2.

The lattice parameters of $\mathrm{ZnO}$ thin films prepared at different temperatures are characteristic of a hexagonal unit with $\mathrm{a}=3.251 \AA$ and $\mathrm{c}=$ $5.223 \AA$. The c values are slightly higher than that of $\mathrm{ZnO}$ standard (JCPDS Card No. 05-0664). The $\mathrm{ZnO}$ preferentially oriented along c-axis suggests that the value of the surface free energy is minimum for the $\mathrm{ZnO}(002)$ plane at the growth stage [20].

\subsection{Morphological studies and EDS}

The micrographs of $\mathrm{ZnO}$ films deposited at 400, 450 and $500{ }^{\circ} \mathrm{C}$, obtained by scanning electron microscopy show the homogeneous structure of the films. The $\mathrm{ZnO}$ film deposited at $400{ }^{\circ} \mathrm{C}$ has an amorphous structure (Fig. 3a), whereas that deposited at $450{ }^{\circ} \mathrm{C}$ contains crystal grains with a hexagonal structure, of the sizes of $100 \mathrm{~nm}$. (Fig. 3b). The $\mathrm{ZnO}$ film deposited at $500{ }^{\circ} \mathrm{C}$ contains the largest grains (Fig. 3c) with an average grain size of about $200 \mathrm{~nm}$. These micrographs confirm the results obtained by the X-ray diffraction studies. In addition, the chemical analysis indicates that the nominal composition has been substantially achieved. In the EDS pattern shown in Fig. $3 \mathrm{~d}$ the presence of the elements $\mathrm{Zn}$ and $\mathrm{O}$ in the layers is indicated, which confirms that they are made of $\mathrm{ZnO}$.

\subsection{Optical properties}

Fig. 4 presents the optical transmittance in the wavelength range of 300 to $1100 \mathrm{~nm}$ for the $\mathrm{ZnO}$ thin films deposited at $\mathrm{T} 400,450$ and $500{ }^{\circ} \mathrm{C}$. The average transmittance in the visible part of the

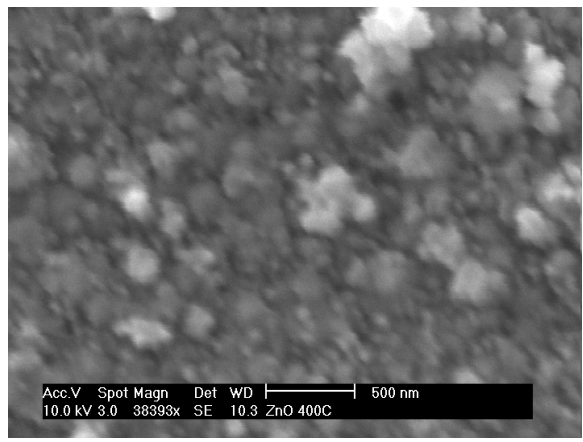

(a)

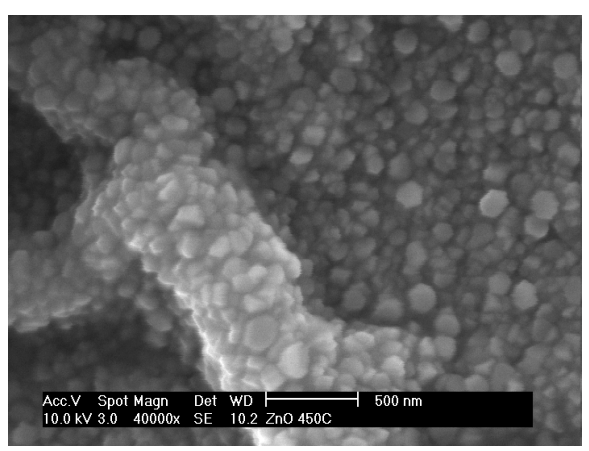

(b)

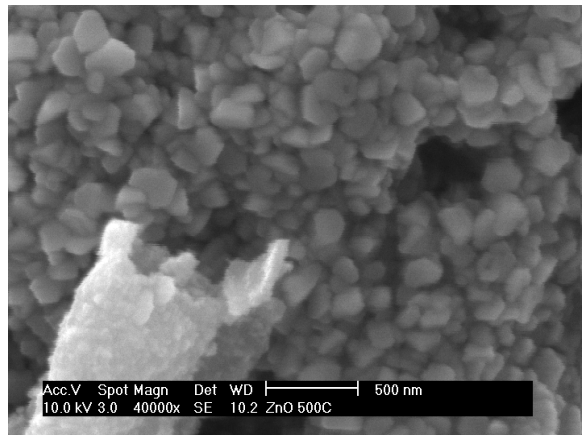

(c)

Label A: Analyse globale ZnO

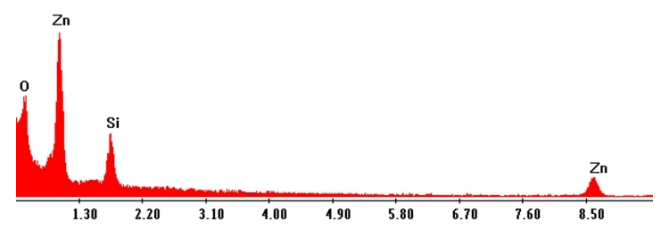

(d)

Fig. 3. SEM micrographs of the $\mathrm{ZnO}$ films deposited at (a) 400, (b) 450 , (c) $500{ }^{\circ} \mathrm{C}$ and (d) results of EDS analysis. 
Table 1. Structural parameters of $\mathrm{ZnO}$ thin films.

\begin{tabular}{|c|c|c|c|c|c|c|c|c|}
\hline Sample & $\begin{array}{l}\text { Pos. } \\
{\left[{ }^{\circ} 2 \theta\right]}\end{array}$ & (hkl) & $\begin{array}{r}\text { FWHM } \\
{\left[{ }^{\circ} 2 \theta\right]}\end{array}$ & $\begin{array}{c}\text { d-spacing } \\
{[\AA]}\end{array}$ & $\begin{array}{r}\text { Rel. Int. } \\
\text { [\%] }\end{array}$ & $\begin{array}{c}\text { Crystallite size } \\
{[\AA \AA]}\end{array}$ & $\begin{array}{r}\mathrm{D}_{\text {moy }} \\
{[\AA]}\end{array}$ & $\begin{array}{c}\text { Lattice strain } \\
{[\%]}\end{array}$ \\
\hline \multirow{3}{*}{$\mathrm{ZnO} 400{ }^{\circ} \mathrm{C}$} & 31.776 & (100) & 0.603 & 2.814 & 57.15 & 143 & \multirow{3}{*}{368} & 0.923 \\
\hline & 34.429 & $(002)$ & 0.494 & 2.603 & 100.00 & 178 & & 0.696 \\
\hline & 36.249 & (101) & 0.618 & 2.476 & 76.65 & 141 & & 0.823 \\
\hline \multirow{3}{*}{$\mathrm{ZnO} 450^{\circ} \mathrm{C}$} & 31.750 & (100) & 0.476 & 2.816 & 3.90 & 184 & \multirow{3}{*}{500} & 0.731 \\
\hline & 34.418 & (002) & 0.354 & 2.603 & 100.00 & 254 & & 0.497 \\
\hline & 36.209 & (101) & 0.482 & 2.479 & 17.44 & 183 & & 0.644 \\
\hline \multirow{3}{*}{$\mathrm{ZnO} 500^{\circ} \mathrm{C}$} & 31.620 & (100) & 0.389 & 2.827 & 8.54 & 227 & \multirow{3}{*}{564} & 0.600 \\
\hline & 34.277 & (002) & 0.337 & 2.614 & 100.00 & 268 & & 0.477 \\
\hline & 36.088 & $(101)$ & 0.426 & 2.487 & 27.47 & 209 & & 0.571 \\
\hline
\end{tabular}

Table 2. Lattice parameters of the $\mathrm{ZnO}$ thin film.

\begin{tabular}{cccc}
\hline Sample & $\mathrm{a}=\mathrm{b}[\AA] \mathrm{c}[\AA]$ & Volume $\left[\AA^{3}\right]$ \\
\hline \hline $\mathrm{ZnO}$ standard & 3.249 & 5.205 & 47.58 \\
$\mathrm{ZnO} 400{ }^{\circ} \mathrm{C}$ & 3.251 & 5.208 & 47.67 \\
$\mathrm{ZnO} 450{ }^{\circ} \mathrm{C}$ & 3.251 & 5.223 & 47.81 \\
$\mathrm{ZnO} \mathrm{500}{ }^{\circ} \mathrm{C}$ & 3.256 & 5.207 & 47.81 \\
\hline
\end{tabular}

spectra (400 to $800 \mathrm{~nm}$ ) was over $80 \%$. The absorption coefficient $\alpha$ of the $\mathrm{ZnO}$ film was determined from the transmittance measurements. The optical absorption was analyzed by the following equation:

$$
\alpha h v=A(h v-E g)^{0.5}
$$

where $\mathrm{A}$ is a constant. The variation of $(\alpha \mathrm{h} v)^{2}$ with photon energy (hv) for the $\mathrm{ZnO}$ thin film is shown in Fig. 5. It has been observed that the plots of $(\alpha \mathrm{h} v)^{2}$ versus $(\mathrm{h} v)$ are linear over a wide range of photon energies indicating the direct type of transitions. The extrapolations of these straight lines on the energy axis give the energy band gaps. The measured optical band gap values were in the range of 3.25 to $3.32 \mathrm{eV}$, which is very close to the band gap of intrinsic $\mathrm{ZnO}$ powder and are in good agreement with the literature reports $[21,22]$.

\subsection{RBS analysis}

The composition and thickness of the layers formed were determined simulating the experimental spectra RBS obtained by the RUMP software

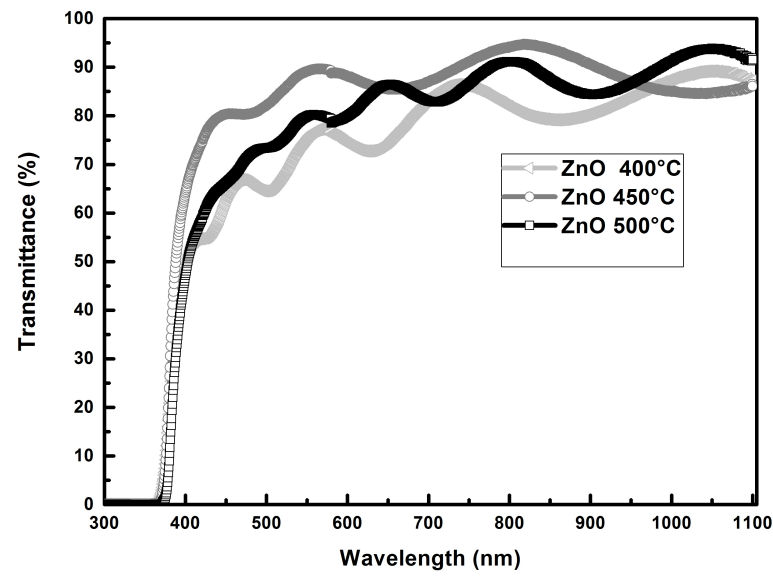

Fig. 4. Transmittance spectra of $\mathrm{ZnO}$ thin films at different temperatures.

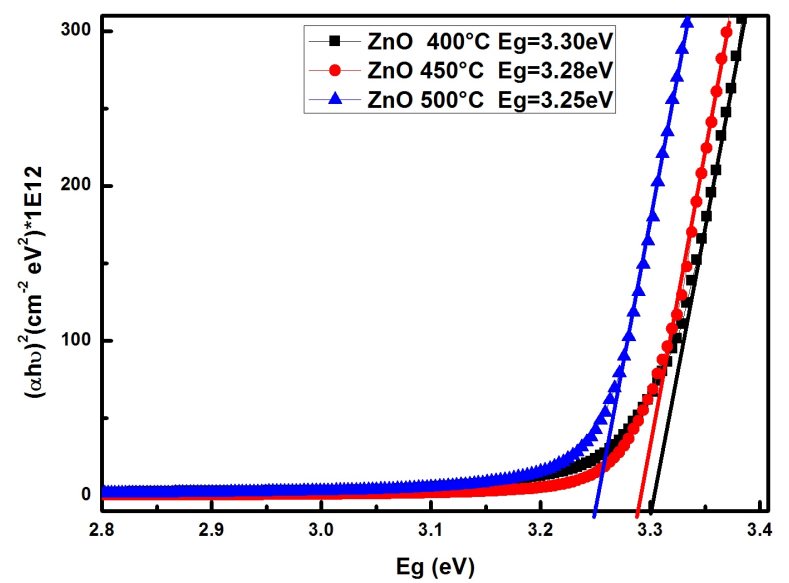

Fig. 5. $(\alpha \mathrm{h} v)^{2}$ as a function of photon energy for the $\mathrm{ZnO}$ thin films deposited at different temperatures 400,450 and $500{ }^{\circ} \mathrm{C}$. 
Table 3. Composition and thickness of $\mathrm{ZnO}$ at $\mathrm{T}=400,450$ and $500{ }^{\circ} \mathrm{C}$.

\begin{tabular}{ccc}
\hline Sample & $\begin{array}{c}\text { Composition } \\
\text { of the layer }\end{array}$ & $\begin{array}{c}\text { Thickness of } \\
\text { the layer }(\mathrm{nm})\end{array}$ \\
\hline \hline $\mathrm{ZnO} 400{ }^{\circ} \mathrm{C}$ & 50.7 at.\% of $\mathrm{Zn}$ and 49.3 at $\%$ of $\mathrm{O}$ & 220 \\
$\mathrm{ZnO} 450{ }^{\circ} \mathrm{C}$ & 55 at. $\%$ of $\mathrm{Zn}$ and 45 at $\%$ of $\mathrm{O}$ & 180 \\
$\mathrm{ZnO} 500{ }^{\circ} \mathrm{C}$ & 50.7 at. $\%$ of $\mathrm{Zn}$ and 49.3 at $\%$ of $\mathrm{O}$ & 220 \\
\hline
\end{tabular}

at the standard experimental conditions: particle beam $4 \mathrm{He}+$ mono $2 \mathrm{MeV}$ energy, at an angle of detection of $165^{\circ}$. The results obtained are also given in Table 3. RBS measurements shown in Fig. 6 reveal that the $\mathrm{ZnO}$ layers are stoichiometric, with a composition of 50.7 at.\% of $\mathrm{Zn}$ and 49.3 at.\% of oxygen. This result confirms the result of EDS and is in good agreement with other results [23]. The thicknesses of the $\mathrm{ZnO}$ films at 400, 450 and $500{ }^{\circ} \mathrm{C}$ obtained from the simulation data are, respectively, $225 \mathrm{~nm}, 200 \mathrm{~nm}$ and $225 \mathrm{~nm}$ (Table 3).

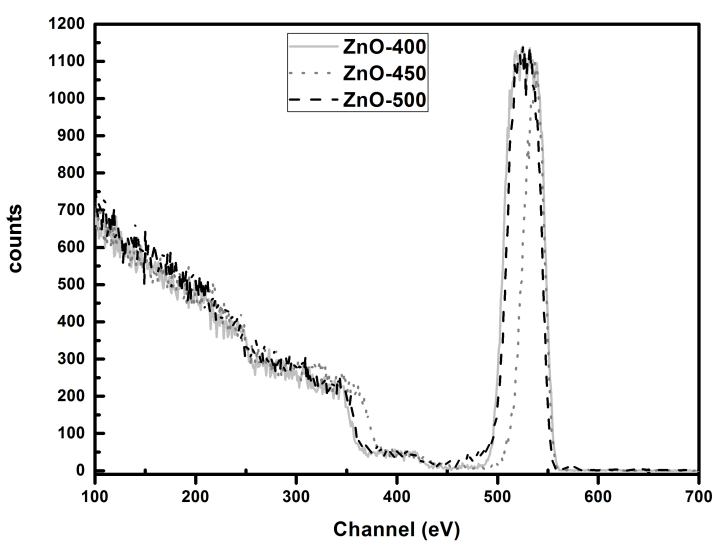

Fig. 6. Superposition of RBS spectra of samples $\mathrm{ZnO}$ at $\mathrm{T}=400,450$ and $500{ }^{\circ} \mathrm{C}$.

\subsection{Electrical studies}

Fig. 7 shows the variation of sheet resistance (Rs) of $\mathrm{ZnO}$ films at different temperatures obtained by four-point technique. The study of the influence of the temperature allowed us to determine the optimum deposition temperature. The selected optimal temperature is $450{ }^{\circ} \mathrm{C}$ because the deposited layers have the lowest sheet resistance of $1000 \Omega$ and good transparency of $80 \%$. The thermoelectric determination of the type of conductivity of the film by the technique of the heated electrode enabled us to confirm that our $\mathrm{ZnO}$ films have a conductivity of n-type.

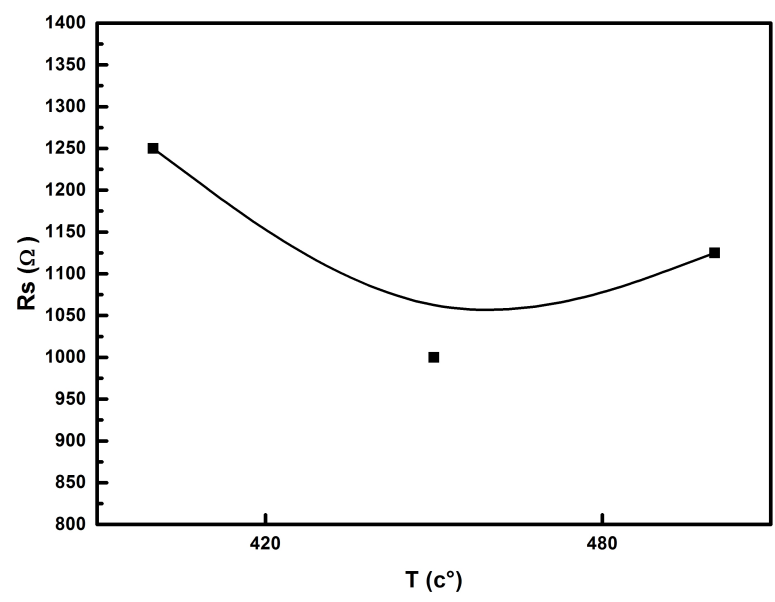

Fig. 7. Variation of the sheet resistance $\left(\mathrm{R}_{\mathrm{s}}\right)$ of $\mathrm{ZnO}$ film at different temperatures.

\section{Conclusions}

Substrate temperatures have a considerable effect on the properties of undoped $\mathrm{ZnO}$ thin films deposited by spray pyrolysis. At high temperature, the crystallinity and grain size are improved. In fact, X-ray patterns show a preferential orientation, which is (002). The average grain size is about $56 \mathrm{~nm}$. The lattice parameters are larger than that of standard $\mathrm{ZnO}$, which shows that these films are constrained. The grain size increases with temperature. The SEM images have revealed a uniform surface, with the presence of crystallite grains. The RBS measurements have shown that $\mathrm{ZnO}$ films are stoichiometric, with an atomic composition of $\mathrm{Zn}$ $(50.7 \%)$ and $\mathrm{O}(49.3 \%)$. The transmission spectra show that the films have a good transparency (80 to $90 \%$ ) in the visible range. 


\section{References}

[1] Ambia M.G., Islam M.N., Obaidul Hakim M., Sol. Ener. Mat. Sol. C., 28 (2) (1992), 103.

[2] Goyal D.J., Agashe C., Takwale M.G., Marathe B.R., Bhide V.G., J. Mater. Sci., 27 (17) (1992), 4705.

[3] BaKha Y., Bendimerad K.M., Hamzaoui S., Eur. Phys. J. - Appl. Phys., 55 (2011), 30103.

[4] FA ̈̈ S., Shah A., Zinc Oxide Grown by CVD Process as Transparent Contact for Thin Film Solar Cell Applications, in: Ellmer K., KLEIN A., ReCH B., (Eds.) Transparent Conductive Zinc Oxide. Basics and Applications in Thin Film Solar Cells, Springer Series in Materials Science, Vol. 104, Springer Berlin Heidelberg, 2008, pp. $235-302$.

[5] Bouderbala M., Hamzaoui S., Stambouli A.B., Bouziane H., Appl. Energ., 64 (1 - 4) (1999), 89.

[6] Zhang X.-A., Zhang J.-W., Zhang W.-F., Wang D., Bi Z., Bian X.-M., Hou X., Thin Solid Films, 516 (10) (2008), 3305.

[7] Kamalasanan M.N., Chandra S., Thin Solid Films, $288(1-2)(1996), 112$.

[8] Olvera de la M.L., Maldonado A., VegaPérez J., Solorza-Feria O., Mater. Sci. Eng. BAdv., 174 (1 - 3) (2010), 42.

[9] DutTa V., Energy Procedia, 3 (2011), 58.

[10] Vimalkumar T.V., Poornima N., Sudha Kartha C., Vijayakumar K.P., Appl. Surf. Sci., 256 (20) (2010), 6025.

[11] Ashour A., KAID M.A., El-SAYEd N.Z., Ibrahim A.A., Appl. Surf. Sci., 252 (22) (2006), 7844.

[12] Banerjee A.N., Gosh C.K., Chattopadhya K.K., Minoura H., Sarkar A.K., AKiba A., KamiYa A., ENDo T., Thin Solid Films, 496 (1) (2006), 112.
[13] Kim H.W., Kim N.H., LEE C., RyU J.H., LEE N.E., J. Korean Phys. Soc., 44 (2004), 14.

[14] Ma T.Y., KIM S.H., Moon H.Y., PARK G.C., KIM Y.J., KIM K.W., Jpn. J. Appl. Phys., 35 (1996), 6208.

[15] FAn X.M., Lian J.S., GuO Z.X., Lu H.J., J. Cryst. Growth, 279 (2005), 447.

[16] Banerjee A.N., Ghosh C.K., Chattopadhyay K.K., Minoura H., SARKar A.K., AKIBA A., KAmiya A., Endo T., Thin Solid Films, 496 (2006), 112.

[17] Dikovska A.O., Atanasov P.A., Vasilev C., Dimitrov I.G., StoYANCHOV T.R., J. Optoelectron. Adv. M., 7 (2005), 1329.

[18] SCHERRER P., Nachr. Ges. Wiss. Göttingen, 2 (1918), 96.

[19] Schroder D.K., Semiconductor Material and Device Characterization, Wiley, New York, 1990.

[20] Cullity B.D., Elements of X-ray Diffraction, Addison-Wesley, Reading, MA, 1978, p. 102.

[21] Prasada Rao T., Santhosh Kumar M.C., AnBumozhi Angayarkanni S., Ashok M., J. Alloy. Compd., 485 (1 - 2) (2009), 413.

[22] Ilican S., Caglar M., Caglar Y., Mater. Sci.Poland, 25 (2007), 715.

[23] Craciun V., Perriere J., Bassim N., Singh R.K., Craciun D., Spear J., Appl. Phys. A, 25 (1999), 531.

Received 2014-06-15 Accepted 2015-03-26 